University of Nebraska - Lincoln

DigitalCommons@University of Nebraska - Lincoln

\title{
Temporal flux and spatial dynamics of nutrients, fecal indicators, and zoonotic pathogens in anaerobic swine manure lagoon water
}

Michael R. McLaughlin

USDA-ARS, mike.mclaughlin@ars.usda.gov

John P. Brooks

USDA-ARS

Ardeshir Adeli

USDA-ARS

Follow this and additional works at: https://digitalcommons.unl.edu/usdaarsfacpub

McLaughlin, Michael R.; Brooks, John P.; and Adeli, Ardeshir, "Temporal flux and spatial dynamics of nutrients, fecal indicators, and zoonotic pathogens in anaerobic swine manure lagoon water" (2012). Publications from USDA-ARS / UNL Faculty. 1166.

https://digitalcommons.unl.edu/usdaarsfacpub/1166

This Article is brought to you for free and open access by the U.S. Department of Agriculture: Agricultural Research Service, Lincoln, Nebraska at DigitalCommons@University of Nebraska - Lincoln. It has been accepted for inclusion in Publications from USDA-ARS / UNL Faculty by an authorized administrator of DigitalCommons@University of Nebraska - Lincoln. 


\title{
Temporal flux and spatial dynamics of nutrients, fecal indicators, and zoonotic pathogens in anaerobic swine manure lagoon water ${ }^{\text {ts }}$
}

\author{
Michael R. McLaughlin*, John P. Brooks, Ardeshir Adeli \\ USDA-ARS, Crop Science Research Laboratory, 810 Hwy 12 E, Mississippi State, MS 39762, USA
}

\section{A R T I C L E I N F O}

\section{Article history:}

Received 2 March 2012

Received in revised form

31 May 2012

Accepted 11 June 2012

Available online 23 June 2012

Keywords:

Confined animal feeding operation

(CAFO)

Clostridium perfringens

Escherichia coli

Campylobacter

Listeria

Salmonella

\begin{abstract}
A B S T R A C T
Confined animal feeding operations (CAFOs) often use anaerobic lagoons for manure treatment. In the USA, swine CAFO lagoon water is used for crop irrigation that is regulated by farm-specific nutrient management plans (NMPs). Implementation of stricter US environmental regulations in 2013 will set soil P limits; impacting land applications of manure and requiring revision of NMPs. Precise knowledge of lagoon water quality is needed for formulating NMPs, for understanding losses of $\mathrm{N}$ and $\mathrm{C}$ in ammonia and greenhouse gas emissions, and for understanding risks of environmental contamination by fecal bacteria, including zoonotic pathogens. In this study we determined year-round levels of nutrients and bacteria from swine CAFO lagoon water. Statistical analysis of data for $\mathrm{pH}$, electrical conductivity $(\mathrm{EC})$, inorganic and organic $\mathrm{C}$, total $\mathrm{N}$, water-soluble and total minerals (Ca, $\mathrm{Cu}, \mathrm{Fe}, \mathrm{K}, \mathrm{Mg}, \mathrm{Mn}, \mathrm{P}$, and $\mathrm{Zn}$ ) and bacteria (Escherichia coli, enterococci, Clostridium perfringens, Campylobacter spp., Listeria spp., Salmonella spp., and staphylococci) showed that all differed significantly by dates of collection. During the irrigation season, levels of total $\mathrm{N}$ decreased by half and the N:P ratio changed from 9.7 to 2.8. Some seasonal differences were correlated with temperature. Total $\mathrm{N}$ and inorganic $\mathrm{C}$ increased below $19{ }^{\circ} \mathrm{C}$, and decreased above $19^{\circ} \mathrm{C}$, consistent with summer increases in ammonia and greenhouse gas emissions. Water-soluble $\mathrm{Cu}, \mathrm{Fe}$, and $\mathrm{Zn}$ increased with higher summer temperatures while enterococci and zoonotic pathogens (Campylobacter, Listeria, and Salmonella) decreased. Although their populations changed seasonally, the zoonotic pathogens were present year-round. Increasing levels of $E$. coli were statistically correlated with increasing $\mathrm{pH}$. Differences between depths were also found. Organic C, total nutrients (C, Ca, Cu, Fe, $\mathrm{Mg}, \mathrm{Mn}, \mathrm{N}, \mathrm{P}$, and $\mathrm{Zn}$ ) and C. perfringens were higher in deeper samples, indicating stratification of these parameters. No statistical interactions were found between collection dates and depths.
\end{abstract}

Published by Elsevier Ltd.

\footnotetext{
ts Journal article number J-12078 of the Mississippi Agricultural and Forestry Experiment Station. Mention of a trade name, proprietary product, or specific equipment does not constitute a guarantee or warranty by the USDA and does not imply its approval to the exclusion of other products that may be suitable. This work was prepared by employees of the U.S. Government as part of their official duties and is in the public domain and may be used without further permission.

* Corresponding author. Tel.: +1 662320 7407; fax: +1 6623207528.

E-mail address: mike.mclaughlin@ars.usda.gov (M.R. McLaughlin). 0043-1354/\$ - see front matter Published by Elsevier Ltd. http://dx.doi.org/10.1016/j.watres.2012.06.023
} 


\section{Introduction}

Open anaerobic lagoons provide primary manure treatment for confined animal feeding operations (CAFOs) in the southeastern USA. Lagoon water is continuously pumped to flush barn pits and is seasonally pumped to supply spray irrigation systems with water and fertilizer nutrients for summer crops (Sistani et al., 2008). Water for irrigating crops may be landapplied only from spring through fall in compliance with site-specific nutrient management plans under EPA - (US Environmental Protection Agency) regulated state permits. In 2013 the US will implement a revised standard for nutrient management plans (Sharpley et al., 2011). The new standard will give greater emphasis to soil $P$ levels and require state-bystate and farm-by-farm revision of current plans. In Europe, a reduced land base available for manure spreading also requires careful manure nutrient management (Webb et al., 2005; Oenema et al., 2007).

Nutrient management plans typically concern only crop fertilization requirements and $\mathrm{N}$ and $\mathrm{P}$ levels in irrigated soils, and do not address microbial levels in the soils or in the wastewater used for irrigation. The US-EPA regulates standards for microbial levels in drinking water, but not for animal agricultural sources of irrigation water applied to pasture and hay crops (Bradford et al., 2008; USEPA and USAID, 2004). Regulatory standards and recommendations for reuse of agricultural wastewater are based on fecal coliform levels, and vary widely (Gerba and Smith, 2005). Recommendations to the World Health Organization (WHO) (Blumenthal et al., 2000) suggest acceptable fecal coliform counts up to $\leq 1 \times 10^{5} 100 \mathrm{~mL}^{-1}$ for spray irrigation of pasture and fodder crops. The WHO guidelines (WHO, 2006) suggest crop-based targets for reduction of fecal bacteria counts in wastewater used for irrigation. In the US, individual state standards for coliforms are as low as 2.2 fecal coliforms $100 \mathrm{~mL}^{-1}$ for wastewater reused on nonfood crop land in Hawaii (USEPA and USAID, 2004). Coliforms and other fecal bacteria are good indicators of fecal contamination, but poor indicators of contamination by zoonotic bacteria. A 2009 report of anaerobic swine manure lagoons in the southeastern US (McLaughlin et al., 2009) found that levels of thermotolerant coliforms and enterococci were poorly correlated with levels of Campylobacter spp. and Salmonella spp., and were not correlated with levels of Listeria spp., despite the high incidence of these zoonotic bacteria across 37 lagoons tested (100, 89 , and 81 percent, respectively). That report concluded that these indicator bacteria should not be used to estimate zoonotic bacterial levels and that direct testing was required for detection of zoonotic bacteria in swine lagoon water.

In a recent review Davies (2011) highlighted the need for quantitative information on enteric zoonotic bacteria in the pork production environment in order to accurately assess risks and improve food safety. Because many earlier studies of swine anaerobic lagoon water were conducted during the summer crop irrigation season (Sistani et al., 2008) and did not include microbial data, these studies provide only limited water quality data. More recent studies of temporal changes in swine anaerobic lagoons reported significant seasonal variability in the nutrient and microbial content of lagoon water
(Lovanh et al., 2009; Cook et al., 2010; Westerman et al., 2010). Lovanh et al. (2009) and Cook et al. (2010) used molecular analyses to estimate total bacterial levels, but except for Clostridium spp., did not report levels of zoonotic bacteria. In an earlier report from North Carolina, Hill and Sobsey (2003) measured year-round levels of fecal bacteria, including Clostridium perfringens and Salmonella spp., in swine waste lagoons. These few reports and their limited coverage of zoonotic pathogens point toward the need for a more comprehensive temporal analysis of bacterial populations, especially zoonotic pathogens, in anaerobic swine manure lagoon water. Additional data were needed for a more complete temporal picture of nutrients, fecal bacteria (including zoonotic species), and coincident environmental factors that may interact with nutrients and bacteria to impact lagoon water quality, nutrient management plans, and risk assessments associated with use of anaerobic treatment lagoons.

The present study was conducted to obtain data on temporal and spatial changes in nutrient and bacterial levels of swine anaerobic lagoon water and to test the null hypothesis that respective nutrient and bacterial levels in lagoon water would not differ by time of year or depth in the lagoon water column. Our objectives were to measure and compare levels of nutrients and bacteria (including fecal indicators and zoonotic species) in swine anaerobic lagoon water collected in different seasons and at different depths and to assess potential correlations of environmental variables with any observed changes in these levels. Nutrient and bacterial levels in a 3.4-ha anaerobic swine CAFO sow farm lagoon were determined at 5-10-wk intervals and at two depths over a 14month period and analyzed to document temporal and spatial differences. Correlations of nutrient and bacterial levels with air and lagoon water temperature, and lagoon water $\mathrm{pH}$, are described. Implications for lagoon management and NMPs are presented.

\section{Materials and methods}

\subsection{Lagoon site}

Water samples were collected from a single-stage 3.4-ha anaerobic swine manure lagoon in east central Mississippi. The lagoon was $2.4 \mathrm{~m}$ deep and had a capacity of $7.6 \times 10^{4} \mathrm{~m}^{3}$. The lagoon had been in continuous operation for 17 years and had an appreciable bottom sludge layer of unknown depth. The lagoon received fresh manure slurry directly from 13 confinement barns, on a sow farm (Fig. 1). The lagoon water retained a permanent red-purple color, which is characteristic of mature phototrophic (purple sulfur bacteria) lagoons (Chen et al., 2003). Each barn typically housed 220-1000 gilts for breeding and gestation, or 384 sows and 3500 piglets during farrowing. Lagoon water was pumped from the lagoon for irrigating and fertilizing warm season grass hay crops on the farm from April through September; land application was not permitted from October through March. Thus, the annual lagoon cycle was one of reducing the lagoon water volume during the drier warm season to accommodate increased rainfall water volume during the cooler season. Nutrient 


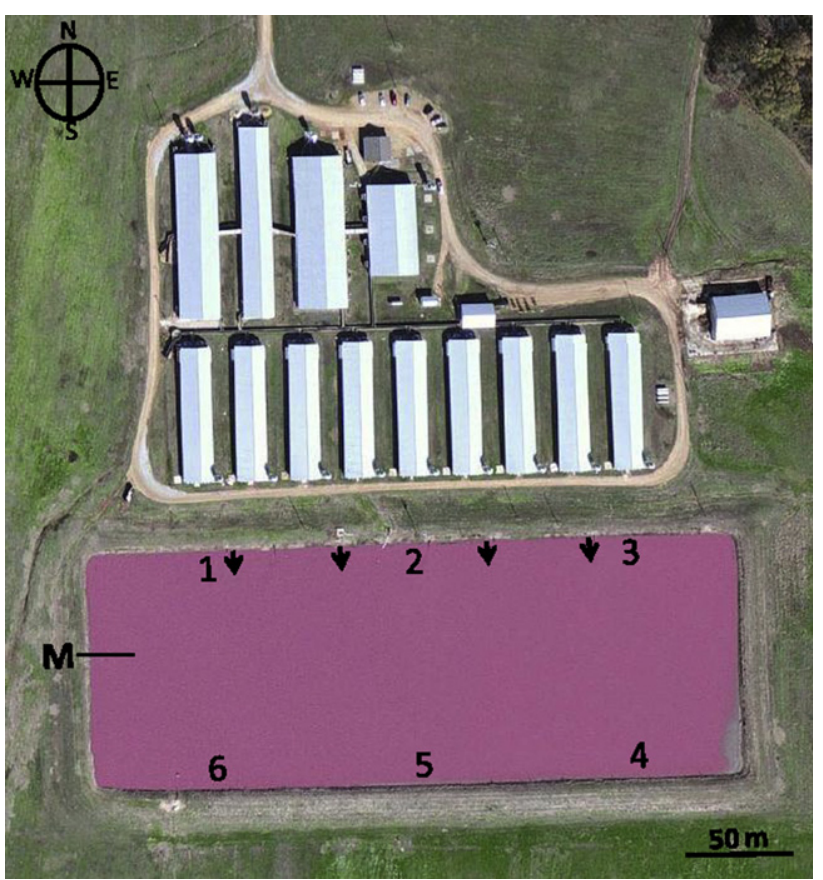

Fig. 1 - Aerial image (courtesy of the U.S. Geological Survey) of the anaerobic lagoon and swine CAFO used in the present study. Lagoon labels show the direction of manure slurry influent flow (arrows), the locations of six water sample collection sites (1-6), and the weather and lagoon temperature monitoring station (M) with lagoon temperature probe (bar).

levels and some bacterial levels in water from the lagoon had been periodically analyzed and reported in other studies (Adeli and Varco, 2001; McLaughlin and Brooks, 2009; McLaughlin et al., 2009) but temporal levels and changes over the annual cycle had not been studied.

\subsection{Environmental monitoring}

Environmental conditions at the lagoon site were monitored continuously using appropriate sensors and data logged electronically using a weather station (Hobo Micro Station, Onset Computer Corp., Bourne, MA) located on the lagoon bank (Fig. 1). Conditions that were monitored included lagoon temperature (via a probe deployed $0.5 \mathrm{~m}$ beneath a floating PVC platform tethered $10 \mathrm{~m}$ from the bank), ambient air temperature, relative humidity, rainfall, ambient solar radiation, and wind speed and direction. Mean hourly and daily values for logged data parameters were determined using HOBOware Pro v.3.2.0 (Onset Computer Corp.) and exported to Microsoft Office Excel 2007 (Microsoft Corporation, Redmond, WA) for additional analyses.

\subsection{Water sample collection}

Water samples were collected on 26 Jan, 9 Mar, 27 Apr, 15 Jun, 17 Aug, 5 Oct, and 16 Dec in 2009 and 22 Feb 2010. On the first two sampling dates, collections were made at three depths
(0.04, 0.47, and $1.0 \mathrm{~m})$, but analyses showed no differences in bacterial levels between 0.04 and $0.47 \mathrm{~m}$ samples (data not shown), so subsequent collections used only 0.04 and $1.0 \mathrm{~m}$ depths and only those results are reported here. Six samples were collected for each depth and date. All samples were collected at the same equidistantly spaced locations along two opposite sides of the lagoon (Fig. 1). Three locations were proximal to the barns and influent flow and three locations were on the opposite side of the lagoon, distal to the barns and influent flow. To avoid collection of sludge and possible plugging of collection lines by sludge, and to allow 1-m deep samples to be drawn from just above the sludge interface, water samples at each location were collected 6-7 m out from the edge of the lagoon. Samples were drawn through sterile silicon tubing using a remote-controlled $12-\mathrm{V}$ DC vacuum pump mounted on a tethered floating collection platform. Samples were drawn into sterile $250-\mathrm{ml}$ polypropylene bottles through luer-lock fittings in custom installed top ports in their sealed caps. For each location, a separate set of collection tubing, cut to length for different sample depths and taped to a PVC pipe (12 mm diameter, $1.5 \mathrm{~m}$ long), was lowered from the collection platform by remote control. Separate sets of bottles, tubing, and PVC pipe were used at each sample collection point. Vacuum source lines and the pump were protected by a $0.22-\mu \mathrm{m}$ inline filter and liquid traps. Samples were placed in a cooler on ice immediately after collection, returned to the laboratory, held at $5^{\circ} \mathrm{C}$, and processed within 3-4 h h of collection.

\subsection{Water sample analyses}

All water samples were analyzed individually. Chemical properties ( $\mathrm{pH}$ and electrical conductivity) and nutrient levels (mg L ${ }^{-1}$ inorganic and organic $\mathrm{C}$, total $\mathrm{N}$, and total and watersoluble (ws) P, K, Ca, Cu, Fe, Mg, Mn, and $\mathrm{Zn}$ ) were determined as previously published (McLaughlin et al., 2009).

Ammonia-nitrogen $\left(\mathrm{NH}_{3}-\mathrm{N}\right)$ flux estimates were calculated using the observational model (Eq. (1)) of Aneja et al. (2000)

$\log _{10}\left(\mathrm{NH}_{3}-\mathrm{N}\right.$ flux $)=0.048 \mathrm{~T}_{\mathrm{L}}+2.1$

with $\mathrm{NH}_{3}-\mathrm{N}$ flux expressed as $\left(\mu \mathrm{g} \mathrm{N} \mathrm{m} \mathrm{Nin}^{-1}\right.$ ) and $\mathrm{T}_{\mathrm{L}}$ measured as lagoon water temperature $\left({ }^{\circ} \mathrm{C}\right)$. $\log _{10} \mathrm{NH}_{3}-\mathrm{N}$ flux estimates (Eq. (1)) were back transformed to $\mathrm{NH}_{3}-\mathrm{N}$ flux ( $\mu \mathrm{g} \mathrm{N} \mathrm{m}^{-2} \mathrm{~min}^{-1}$ ) and plotted over time to estimate seasonal temperature effects.

Bacterial levels (cfu $100 \mathrm{ml}^{-1}$ for enterococci, staphylococci, C. perfringens, and Escherichia coli; and MPN $100 \mathrm{ml}^{-1}$ for Campylobacter spp., Listeria spp., and Salmonella spp.) were determined using cultural and molecular methods as previously published (McLaughlin et al., 2009, 2010).

\subsection{Statistical analyses}

Bacterial count data (cfu or MPN $100 \mathrm{~mL}^{-1}$ ) were adjusted by addition of 1.0 (to convert zeros to positive numbers) and $\log _{10}$-transformed to stabilize the variance for statistical analyses. Transformed bacterial data and raw data for chemical and nutrient analyses were subjected to analysis of 
variance using SAS (v9.2 for Windows XP-Pro, SAS Institute, Inc., Cary, NC) MIXED model analysis of sampling dates (eight) using a repeated measures design with sample location (six) and depth (two) as repeated variables and a heterogeneous autoregressive covariance structure. Data from one sampling date each for Campylobacter (9 Mar 2009), enterococci (16 Dec 2009), and wsZn (16 Dec 2009) did not fit the heterogeneous autoregressive covariance structure, so these variables were analyzed using data for seven dates each and missing data were estimated by linear models for graphical comparisons. Data from six 1-m-depth samples (two from each of three sampling dates) that contained significant amounts of sludge were excluded in the analysis. Main effects in the MIXED model were compared by $F$ tests and differences between means were compared at the $P \leq 0.05$ level. Correlations and graphical analyses were done using Microsoft Office Excel 2007 (Microsoft Corporation) and differences were compared at the $P \leq 0.05$ level, unless stated otherwise.

\section{Results and discussion}

\subsection{Environmental factors}

Local environmental conditions and temporal changes at the lagoon site are shown in Fig. 2. Annual rainfall (Fig. 2a) in the area averages $1400 \mathrm{~mm}$, with higher amounts from late fall through winter to early spring and generally less rainfall in the warm season from mid-April through September, which encompasses the 6-month irrigation season when lagoon water is applied to surrounding crop land. Relative humidity at the lagoon site (Fig. 2b) varied widely, but generally was higher from summer through winter than in spring. Ambient air temperatures (Fig. 2c) displayed typical seasonal fluctuations with highs in mid-summer and lows in mid-winter corresponding with seasonal changes in day length (Fig. 2d). Lagoon water temperature changes paralleled air temperature changes, but averaged about $3{ }^{\circ} \mathrm{C}$ higher (Fig. 2c), an observation also reported by Lovanh et al. (2009) for an anaerobic lagoon in Kentucky. Although seasonal temperature ranges may differ from those reported for lagoons in other regions of the USA, the seasonal pattern reported in the present study is similar to those reported for swine lagoons in Iowa (Merrill and Halverson, 2002), Kansas (DeSutter and Ham, 2005), Kentucky (Cook et al., 2010), and North Carolina (Vanotti and Szogi, 2008). Correlations between air and lagoon temperatures and emissions of ammonia, greenhouse gasses, and malodorants have been widely studied, and it is generally agreed that lagoon water temperature is a significant factor in volatilization processes (Harper et al., 2000; DeSutter and Ham, 2005; Aneja et al., 2008; Blunden and Aneja, 2008; Blanes-Vidal et al., 2010; Loughrin et al., 2011). Correlations observed in the present study are described in 3.2.2., 3.2.3., 3.2.5., and 3.3.1.

\subsection{Chemical properties}

Chemical properties and total nutrient levels of the lagoon water samples are reported in Tables 1 and 2. Tests of sampling date were significant for all variables. Tests of sampling depth were significant for some variables. Property and nutrient means averaged over sampling depth and compared across sampling dates are shown in Table 1. Significant seasonal changes in nutrients with volatile forms a

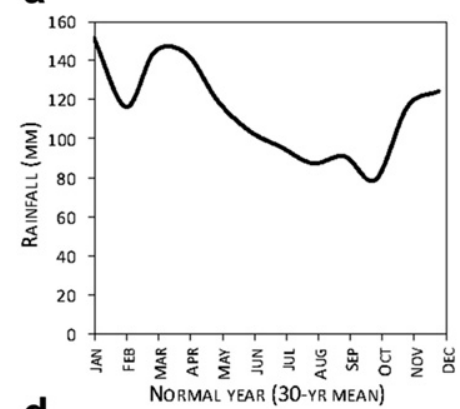

d

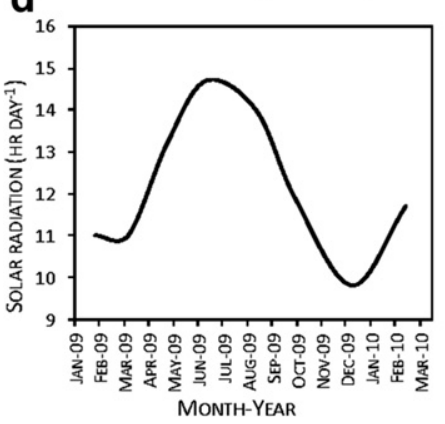

b

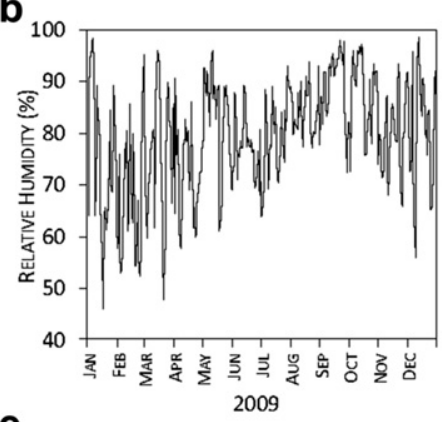

e

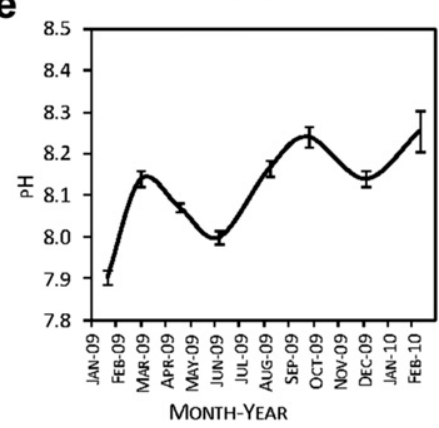

C

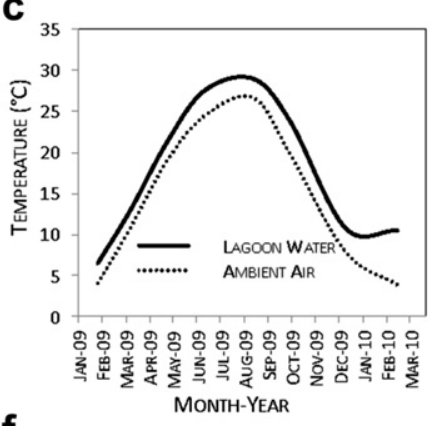

f

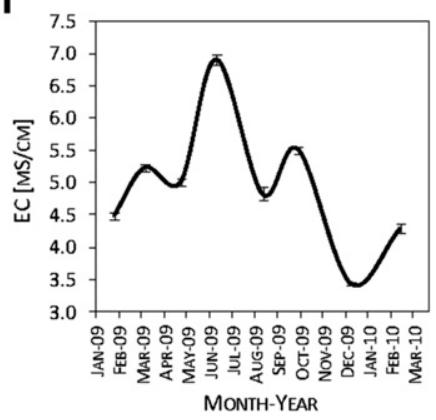

Fig. 2 - Lagoon environmental conditions: (a) normal (30-yr mean) rainfall; (b) mean daily percent relative humidity; (c) mean hourly temperatures for 10-day periods before each lagoon water sample collection; (d) mean daily hours of solar radiation; (e) lagoon water $\mathrm{pH}$; and (f) lagoon water EC. The $\mathrm{pH}$ and EC are combined means ( $\pm \mathrm{SE}$ bars) for 4-cm and 1-m depths at each collection date $(n=12)$. 


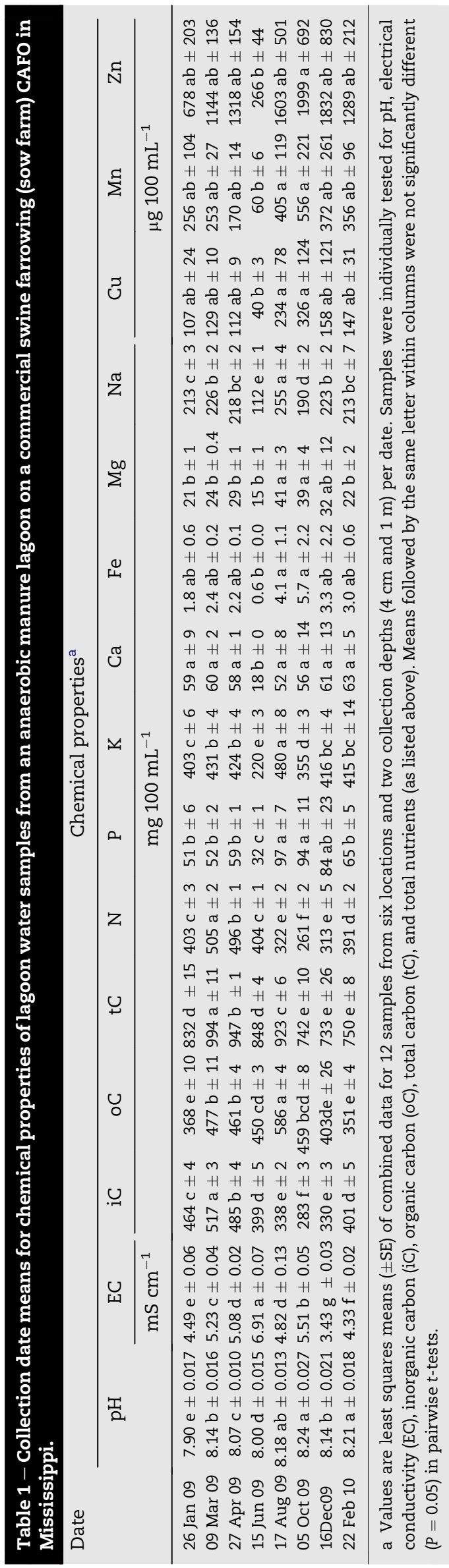

(tN and iC) and in water-soluble metal levels (wsCu, wsFe, wsZn) were observed and are described later (3.2.2. and 3.2.5., respectively). Chemical property and nutrient means averaged over sampling dates and compared between sampling depths are shown in Table 2.

\subsection{1. $p H$ and $E C$}

The $\mathrm{pH}$ of lagoon water samples (Fig. 2e) varied between collection dates (Table 1), but remained within a relatively narrow range (7.9-8.2) that was slightly higher than the range (7.3-7.9) reported for sow farm lagoons in the region (McLaughlin et al., 2009). Mean $\mathrm{pH}$ was statistically higher in shallow (8.13) than deep (8.09) samples (Table 2), but this difference was not correlated with observed changes in nutrients or bacteria and did not appear to be chemically or biologically significant. Although $\mathrm{pH}$ tended to increase slightly through the study period, values remained within the optimal range reported for purple sulfur bacteria (Chen et al., 2003). The $\mathrm{pH}$ flux observed in the present study showed significant correlation only with E. coli levels, as described in 3.3.1.

Electrical conductivity (Fig. 2f) also varied between collection dates (Table 1) with a peak summer mean EC value (6.91 $\pm 0.071 \mathrm{mS} \mathrm{cm}^{-1}$ on 15 Jun 2009) nearly double the lowest winter mean EC value $\left(3.43 \pm 0.021 \mathrm{mS} \mathrm{cm}^{-1}\right.$ on $\left.16 \mathrm{Dec} 2009\right)$ and slightly above the range $\left(2.7-6.0 \mathrm{mS} \mathrm{cm}^{-1}\right)$ reported for sow farms in the region (McLaughlin et al., 2009). The influence of increased summer temperatures on increased solubility of some metals as noted above, and thereby on EC values, are described in 3.2.5.

\subsubsection{Nitrogen, phosphorus and potassium}

Levels of the principal fertilizer nutrients $\mathrm{N}, \mathrm{P}$, and $\mathrm{K}$ varied in lagoon water with dates of collection (Fig. 3), but only $\mathrm{N}$ and $\mathrm{P}$ differed between lagoon depths (Table 2). Annual mean levels of lagoon water $\mathrm{N}\left(393 \mathrm{mg} \mathrm{L}^{-1}\right), \mathrm{P}\left(64 \mathrm{mg} \mathrm{L}^{-1}\right)$, and $\mathrm{K}$ (480 $\mathrm{mg} \mathrm{L}^{-1}$ ) in the present study were similar to those reported earlier $\left(\mathrm{N}=412 \mathrm{mg} \mathrm{L}^{-1} ; \mathrm{P}=61 \mathrm{mg} \mathrm{L}^{-1} ; \mathrm{K}=401 \mathrm{mg} \mathrm{L}^{-1}\right)$ from a 1994-1996 study of irrigation water from this lagoon (Adeli and Varco, 2001). This earlier study, however, did not report levels and changes during these years or irrigation seasons. Furthermore, at the time of the earlier study, the farm was a complete farrow to finish operation, consequently animal numbers and age ratios, feed inputs, and management were different than during the present study and likely produced different lagoon water quality than the present operation.

Annual flux in total $\mathrm{N}$ content of lagoon water in the present study was estimated by a third order polynomial equation $\left(R^{2}=0.98\right)$ as:

$y=6.0 \times 10^{-5} x^{3}-0.034 x^{2}+4.7236 x+309.42$

where $y$ is the concentration of total $\mathrm{N}\left(\mathrm{mg} \mathrm{L}^{-1}\right)$ and $x$ is the day (from one to 366) of the calendar year. To test this simple model (Eq. (2)), data were used from an earlier study (McLaughlin et al., 2009), in which the mean concentration of total $\mathrm{N}$ from six samples of shallow lagoon water had been determined following collection on 5 Sep 2007 (day 249 of the calendar year) from the same lagoon used in the present study. Fitting $x=249$ in Eq. (2) estimated $y=304 \mathrm{mg} \mathrm{N} \mathrm{L}^{-1}$ for the 5 Sep 2007 samples, which, based on the earlier analysis 


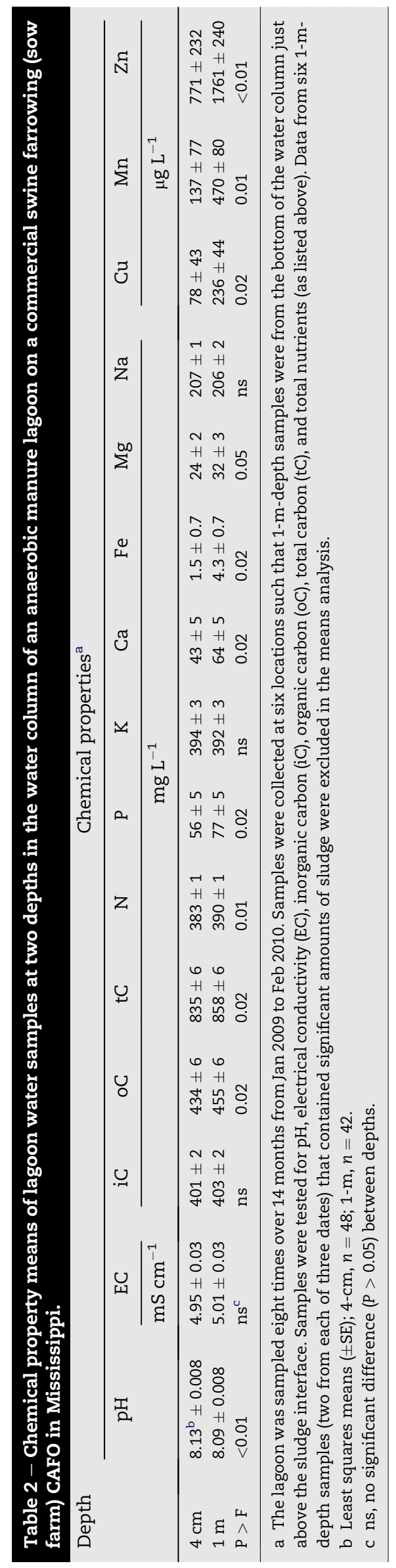

had total $\mathrm{N}=294 \mathrm{mg} \mathrm{L}^{-1}$. The error of the estimate was three percent. This relationship provides a promising practical tool for nutrient management of this particular lagoon within the relatively stable cyclical input parameters that comprise this specific farm operation. With more extensive testing of additional lagoons over multiple years this simple tool might find wider application to other lagoons and locations.

In the present study, levels of $\mathrm{N}$ and $\mathrm{P}$ were higher in 1-m than in 4-cm samples (Table 2). No interactions of date and depth were observed. Because P is often bound to sediment suspended in lagoon water, it was not surprising that deeper samples had higher total $\mathrm{P}$ content. In fact, six 1-m samples containing appreciable amounts of sediment and noted the times of collection as darker in color and high in sludge (likely collected in the sludge interface rather than in lagoon water alone), were excluded from subsequent comparisons of lagoon water nutrient levels (2.5) because of their very high levels of some nutrients, especially $\mathrm{P}$, which were five to ten times higher than other 1-m lagoon water samples collected at the same times from above the sludge interface. Chen et al. (2003) also reported nutrient stratification in sow farm lagoons and Lovanh et al. (2009) showed much higher nutrient levels in the sludge layer beneath the water column than in water samples above.

\subsubsection{Nitrogen and carbon flux}

Nitrogen levels in lagoon water increased during the cool season and decreased steadily during the warm season (Fig. 3a). Westerman et al. (2010) observed a similar seasonal trend weakly correlated with annual rainfall in North Carolina lagoons and suggested that $\mathrm{N}$ losses in summer could be due to increased ammonia emissions. Estimated $\mathrm{NH}_{3}-\mathrm{N}$ flux in the present study showed such a seasonal effect (Fig. 3b), suggesting a temperature effect. Although gaseous emissions from the lagoon were not measured directly in the present study, the pattern of $\mathrm{N}$ loss observed during summer and a similar pattern of inorganic $C$ loss (Fig. 3c) together suggest that gaseous emissions during the warm season played a significant role in reducing the levels of these nutrients in lagoon water. In addition to $\mathrm{N}$ loss from increased $\mathrm{NH}_{3}$ emissions, other important greenhouse gas emissions affected by seasonal temperature changes are carbon dioxide, methane, and nitrous oxide (Kayranli et al., 2010).

Lagoon temperature effects on total $\mathrm{N}$ and inorganic $\mathrm{C}$ levels in lagoon water were further examined by correlation analysis. Changes in total $\mathrm{N}$ and inorganic $\mathrm{C}$ levels were calculated by comparing their respective levels at each collection date with levels at the previous collection date. This calculation assumed annual cyclical changes in both nutrients such that the estimated changes in levels for the first (late winter) collection date (26 Jan 2009) were calculated based on the respective levels for (early winter) samples collected on 16 Dec 2009. Changes in temperature were calculated using hourly mean temperatures for 10 -day periods immediately preceding each respective collection date and determining their respective deviations from an empirically derived threshold of $19{ }^{\circ} \mathrm{C}$. At the threshold temperature, $\mathrm{N}$ and inorganic $\mathrm{C}$ inputs to lagoon water from conversion of manure nutrients in the lagoon should approximate $\mathrm{N}$ and inorganic $\mathrm{C}$ losses (to gaseous emissions) from the lagoon (no net change). 

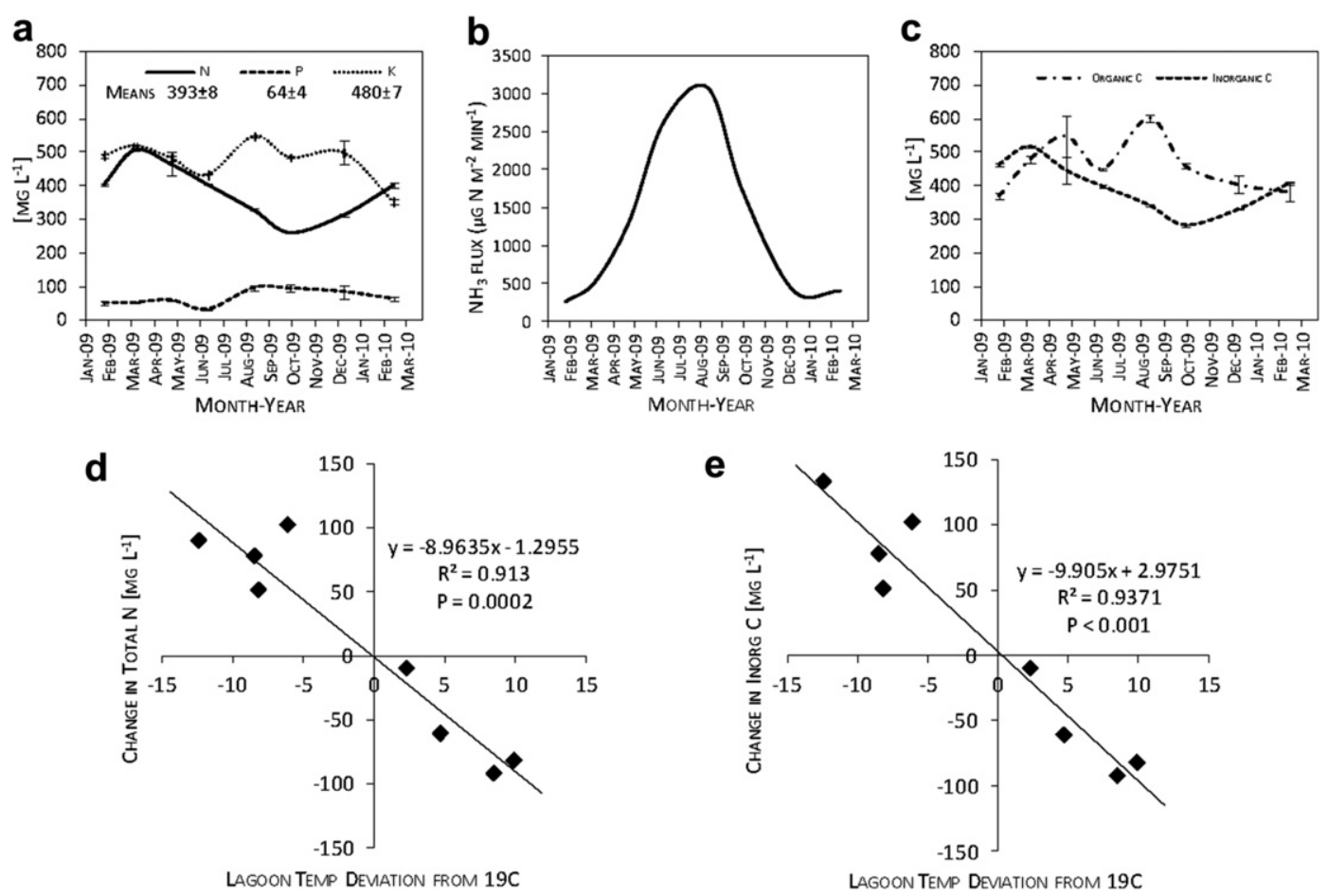

Fig. 3 - Temporal distribution of (a) N, P, and K; (b) estimated temporal $\mathrm{NH}_{3}-\mathrm{N}$ flux from gaseous emissions; and (c) organic and inorganic $\mathrm{C}$ in lagoon water from 26 Jan 2009 through 22 Feb 2010. Models of changes in (d) total N in lagoon water; and (e) inorganic $\mathrm{C}$ in lagoon water based on changes in lagoon water temperature (deviation from $19{ }^{\circ} \mathrm{C}$ in 10 -day hourly mean temperatures before each collection date). Nutrient data are the combined means for 4-cm and 1-m samples ( \pm SE bars for each collection date, $n=12$ ). NPK means shown in the legend in (a) are annual lagoon cycle means ( \pm SE) for combined depths ( $n=90$; excludes six 1.0-m samples which contained significant amounts of sludge; two each on 27 Apr and 17 Aug 2009 and 22 Feb 2010).

At temperatures below this threshold, $\mathrm{N}$ and inorganic $\mathrm{C}$ accumulated in lagoon water. At temperatures above this threshold, $\mathrm{N}$ and inorganic $\mathrm{C}$ losses exceeded inputs. Analyses of changes in levels of $\mathrm{N}$ (Fig. 3d) and inorganic C (Fig. 3e) showed significant correlations with deviations from the threshold temperature. This simple temperature correlation of total $\mathrm{N}$ and inorganic $\mathrm{C}$ levels in lagoon water was consistent with observations of earlier studies (Ibusuki and Aneja, 1984; Harper et al., 2000) and with more recent and comprehensive models (Blanes-Vidal et al., 2010).

\subsection{4. $\quad N: P$}

Total $\mathrm{N}$ and total $\mathrm{P}$ data were also examined as temporal changes in the ratio of $\mathrm{N}$ to $\mathrm{P}$ in lagoon water. This ratio is useful in nutrient management planning for applications of lagoon water in irrigation and fertilization of crops. Total $\mathrm{P}$ levels showed an overall increase during the summer irrigation season, in contrast to the coincident decrease in total $\mathrm{N}$ (Fig. 3a). On 9 Mar 2009 before the start of the irrigation season the $\mathrm{N}$ :P of lagoon water was 9.7. On 5 Oct 2009 at the close of the irrigation season the N:P was 2.8. The irrigation season mean N:P was 6.7 (four sampling dates); and the annual mean $\mathrm{N}: \mathrm{P}$ was 6.8 (eight sampling dates). These results were consistent with the 3-yr irrigation season mean lagoon water $\mathrm{N}$ :P of 6.7 reported in an earlier study of this lagoon (Adeli and Varco, 2001). Consequently, N-based lagoon water applications require informed adjustments during the irrigation season to prevent nutrient insufficiency or excess. Failure to increase application rates as the summer growing season progresses and lagoon water $\mathrm{N}$ levels decline could result in $\mathrm{N}$ insufficiency. Conversely, increasing lagoon water application rates in summer to increase $\mathrm{N}$ rates could result in $\mathrm{P}$ excesses. In the case of summer hay crops, there are many different species and varieties of forage crops available, which offer a range of $\mathrm{N}: \mathrm{P}$ requirements to help growers and nutrient management planners optimize individual nutrient management plans (Sistani et al., 2008). Managing the N:P status of land-applied manures will become even more critical in the future, especially in the USA, following the scheduled 2013 implementation of a revised state-by-state national nutrient management standard establishing upper limits for soil $\mathrm{P}$ levels (Sharpley et al., 2011).

\subsubsection{Other nutrients}

Levels of other nutrients also changed significantly across sampling dates Table 1. While water-soluble and total levels of the highly soluble nutrients, $\mathrm{Ca}$ and $\mathrm{Mg}$, could be expressed on the same respective scales, less soluble nutrients, $\mathrm{Fe}, \mathrm{Cu}$, and $\mathrm{Zn}$, showed 10 -fold differences between their respective total and water soluble levels (data not shown). Assuming relatively stable feed inputs of these nutrients year round, increased levels of water-soluble metals, wsFe, wsCu, and 
a

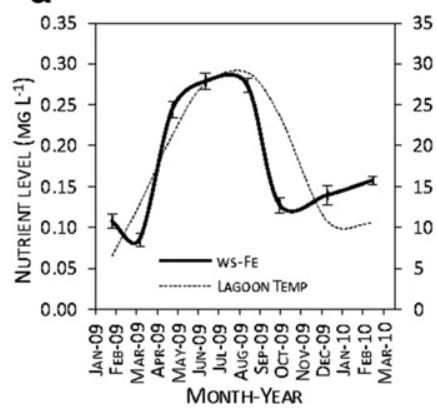

d

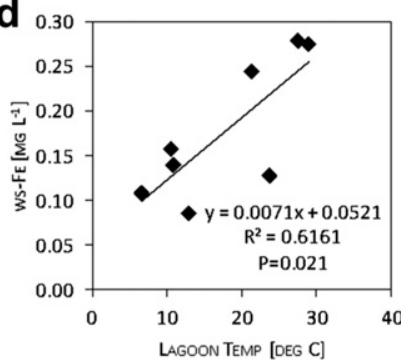

b
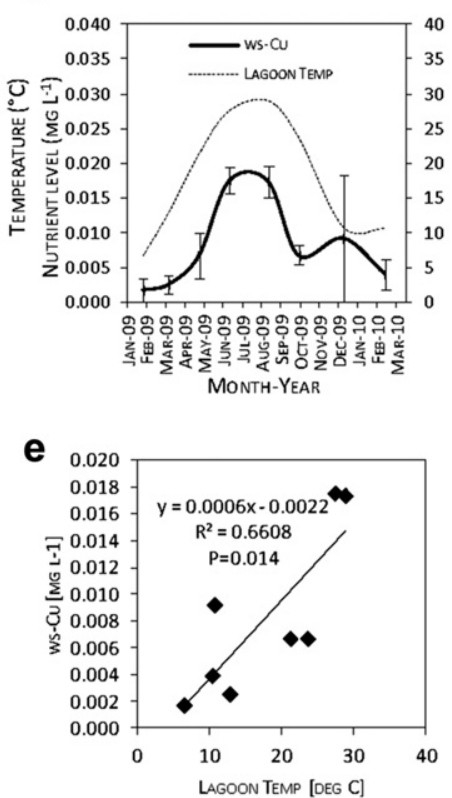

c

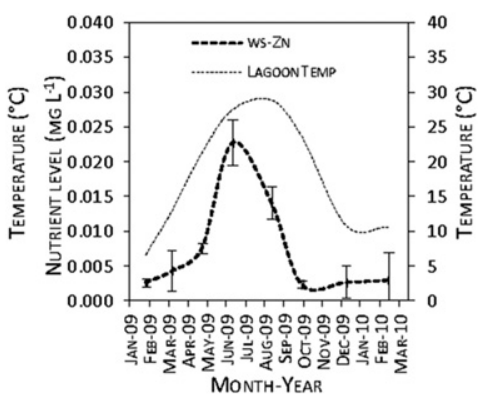

f

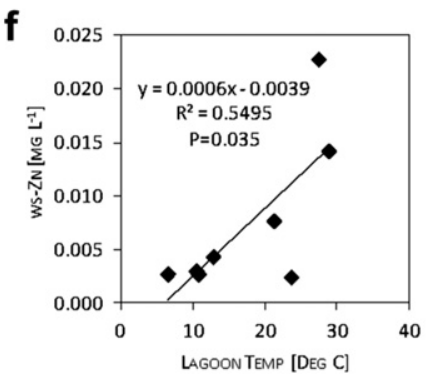

Fig. 4 - Temporal changes in lagoon water temperature and levels of water soluble (ws-) (a) Fe; (b) Cu; and (c) Zn. Combined means $(4 \mathrm{~cm}$ and $1 \mathrm{~m})$ and standard error bars of nutrient levels are shown $(n=12$; excludes six 1.0-m-depth samples which contained significant amounts of sludge, two each on 27 Apr and 17 Aug 2009 and 22 Feb 2010; ws-Zn levels for 16 Dec 2009 were estimated by linear model using 5 Oct 2009 and 22 Feb 2010 data). Linear correlations of nutrient level and lagoon water temperature for (d) $\mathrm{Fe},(e) \mathrm{Cu}$, and (f) $\mathrm{Zn}$.

wsZn, in summer suggested a temperature effect (Fig. $4 a-c$ ). To examine these data for such an effect, water-soluble levels of these three metals were plotted with hourly mean lagoon water temperatures calculated for 10-day periods immediately before each collection date. Temperatures at the time of collection were also examined (data not shown), but appeared more variable and were believed to be more coincidental and less effectual than 10-day means for the periods before sample collections. Linear correlation analyses of wsFe, wsCu, and wsZn levels against lagoon water temperatures showed significant positive correlations and possible temperature effects (Fig. $4 d-f$ ).

Levels of other total nutrients, except for the highly mobile inorganic $\mathrm{C}, \mathrm{K}$, and $\mathrm{Na}$ also differed between depths (Table 2). Levels of organic and total $\mathrm{C}$, and total levels of $\mathrm{Ca}, \mathrm{Cu}, \mathrm{Fe}, \mathrm{Mg}$, $\mathrm{Mn}, \mathrm{N}, \mathrm{P}$, and $\mathrm{Zn}$ were all higher in 1-m water samples than in 4-cm water samples. Such stratification was not unexpected as similar observations have been reported for top and bottom samples from a farrowing farm lagoon in Kentucky (Lovanh et al., 2009) and for water samples from different depths in farrowing farm lagoons in Nebraska (Chen et al., 2003).

\subsection{Bacteria}

Combined bacterial population means $\log _{10}$ (cfu or MPN $100 \mathrm{~mL}^{-1}, n=90$ ) across all sampling dates and both depths were, from highest to lowest: staphylococci (6.4 \pm 0.08$)$; E. coli (6.0 \pm 0.05$) ; C$. perfringens (6.0 \pm 0.05$)$; Campylobacter spp. (4.4 \pm 0.06$)$; enterococci $(4.3 \pm 0.18)$; Listeria spp. ( $2.3 \pm 0.11)$; and Salmonella spp. $(1.4 \pm 0.11)$. The relative order and levels of these respective population means were similar to those reported for sow farms in the region (McLaughlin et al., 2009). Reports of the presence and persistence of these bacterial indicators and pathogens in swine manure lagoons in other states and Canada revealed many single event collections of these bacteria, but few longer term temporal studies (Hill and Sobsey, 2003; Guan and Holley, 2003; McLaughlin and Brooks, 2009). The present study is the first to document temporal changes in zoonotic bacterial pathogen populations in anaerobic swine lagoon water in the Mid-South USA.

\subsubsection{Bacterial temporal flux}

Levels of all bacterial groups enumerated in the present study varied significantly across dates of sample collection (Table 3). The temporal distributions of several of the bacterial groups in the present study, especially Campylobacter spp. and Listeria spp. showed decreases from spring to summer followed by increases in fall, which suggested potential temperature effects. Inactivation effects from increased ultraviolet light exposures might also increase with longer day length, however, the extreme turbidity of the lagoon water likely protected the target bacterial populations from UV light, even at 4-cm depths. Therefore, the respective bacterial groups were analyzed to investigate potential correlations with lagoon temperature only. Significant $(P<0.05)$ correlations with lagoon temperature were found for Campylobacter spp. (Fig. 5a), enterococci (Fig. 5b), Listeria spp. (Fig. 5c), and Salmonella spp. ( $<0.1$ ) (Fig. 5d). Bui et al. (2011) and others (Placha et al., 2001; Arrus et al., 2006) have reported declining survival of Campylobacter coli and Salmonella, respectively, with increasing temperatures in swine waste environments. 
सั $\circ 00000000$ H H H H H H H สิ त 0 O 0000000 H H H H H H H H ๓ 0 0 0

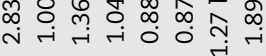
$\begin{array}{llllllll}0 & 0 & 0 & 0 & 0 & 0 & 0 & 0\end{array}$

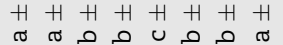
సูลิ तु तु ले

As enteric pathogens, well adapted to animal gut temperatures of $37-39{ }^{\circ} \mathrm{C}$, Salmonella spp. are well adapted to the relatively higher temperatures recorded in the present study from lagoon water in summer $\left(30^{\circ} \mathrm{C}\right)$. Therefore, temperature alone is likely not the direct cause of the observed decline in Salmonella counts. Increased levels of water-soluble metals could be a factor, for although $\mathrm{Cu}, \mathrm{Fe}, \mathrm{Mn}$, and $\mathrm{Zn}$, are important in oxidation-reduction reactions and trace amounts are required for microbial enzymatic processes (Kayranli et al., 2010; Burgin et al., 2011; Glass and Orphan, 2012), higher concentrations of these metals, especially $\mathrm{Cu}$ and Zn, have known microbial toxicity (Özbelge et al., 2005). Both $\mathrm{Cu}$ and $\mathrm{Zn}$ are added to swine diets to improve performance and as antibacterial agents to reduce enteric pathogens and prevent disease (Wells et al., 2010). Other potential factors in the seasonal Salmonella decline include increased solar radiation (Fig. 2d) and increased competition and predation from other bacteria and microorganisms, including bacteriophages (Callaway et al., 2011). Salmonella-specific bacteriophages have been isolated from water samples collected from this and similar lagoons in the area (McLaughlin et al., 2006), although their temporal distribution and concentrations are unknown. Furthermore, the dynamics of Salmonella population flux in lagoon water may not be fully explained by lagoon factors alone. The cyclical nature and continually overlapping litters of the CAFO sow farm farrowing operation, combined with the integrated system of moving replacement gilts and feeder pigs within and between farms, and the constant recycling of lagoon water to flush barn pits, carries the inherent potential for continuous exposure of naïve animals in new litters to Salmonella and subsequent resupply of freshly shed Salmonella in variable but continuous inputs back to the lagoon (Door et al., 2009; Davies, 2011).

Potential correlations of bacterial levels with nutrient levels, $\mathrm{pH}$, and EC were also examined graphically and by correlation analysis. Plotting E. coli and $\mathrm{pH}$ over time showed a potential correlation of E. coli and $\mathrm{pH}$ (Fig. 6a), which was confirmed by correlation analysis (Fig. 6b). No other effects on bacterial levels were found from further analyses of nutrient levels, $\mathrm{pH}$ or EC.

\subsubsection{Bacterial spatial flux}

In the present study, only $C$. perfringens counts differed $(P<0.05)$ between water sample depths, with means of 6.085 $( \pm 0.063) \log _{10} \mathrm{cfu} 100 \mathrm{~mL}^{-1}$ in 1 -m samples $(n=42)$ and 5.89 $( \pm 0.06) \log _{10}$ cfu $100 \mathrm{~mL}^{-1}$ in 4 -cm samples $(n=48)$. Cook et al. (2010), using quantitative polymerase chain (qPCR) reaction methods to compare samples from different depths in a sow farm lagoon in Kentucky over a 12-month period, concluded that species of Clostridiales were widespread in slurry, and reported much higher cell counts than those of the present study. Although statistical analysis of the Cook et al. (2010) data were not reported, estimated cell counts ranged from $<5$ logs $\mathrm{mL}^{-1}$ to $>7$ logs $\mathrm{mL}^{-1}$ with lower counts in some bottom (>198 cm deep) samples, little difference between spatial counts (top, $51 \mathrm{~cm}$, and $152 \mathrm{~cm}$ ), and temporal variations within a range of about 1.5-2 logs. By comparison, results from the present study showed a range from about 5.5 to $6.5 \log _{10}$ cfu $100 \mathrm{~mL}^{-1}$, but higher counts in deeper samples, as noted above. In addition, the present study found even 
a
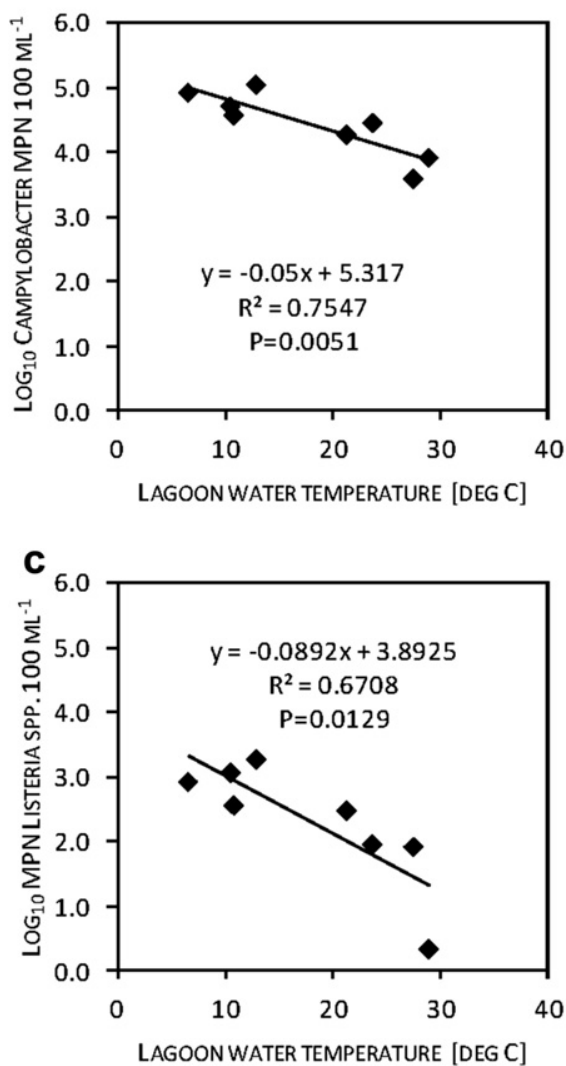

b

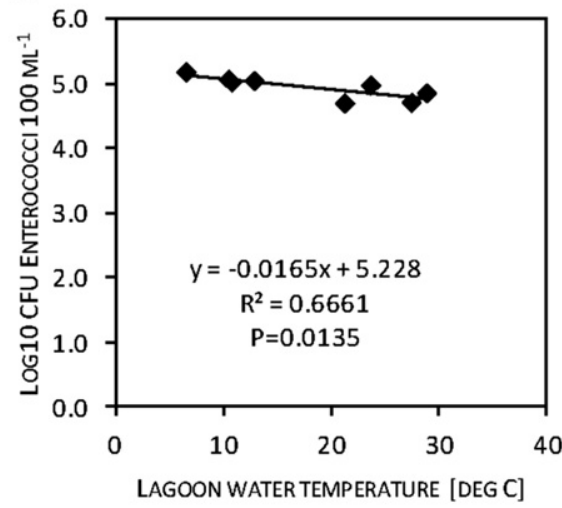

d

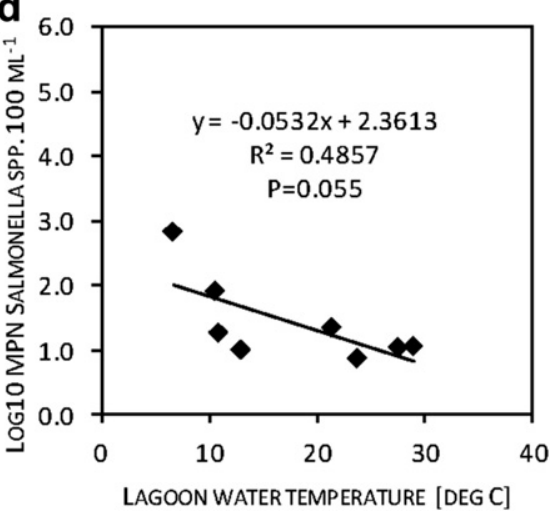

Fig. 5 - Correlations of lagoon water temperature and bacterial counts were significant $(P<0.05)$ for (a) Campylobacter spp., (b) enterococci, (c) Listeria spp., and (d) $(P<0.1)$ Salmonella spp.

higher counts from six 1-m samples (two samples each from 27 Apr and 17 Aug 2009, and 22 Feb 2010) that were excluded in statistical comparisons because they contained appreciable amounts of sludge (3.2.2.). The $C$. perfringens counts from these six sludge-containing samples ranged from 6.7 to $8.3 \log _{10} \mathrm{cfu} 100 \mathrm{~mL}^{-1}$ with a mean of $7.6( \pm 0.5) \log _{10}$ cfu $100 \mathrm{~mL}^{-1}$.

Apparent differences in spatial distribution and magnitude of counts between the study by Cook et al. (2010) and the present study may be due to inherent differences between the respective lagoons and to differences in methodology. Higher overall counts typically result from $\mathrm{qPCR}$, which measures DNA from live and dead cells. Cultural assay in the present study specifically targeted spores by eliminating live somatic cells with a heat shock treatment (McLaughlin et al., 2009). Spore counts and qPCR inhibitors would be expected to be higher in sediment (Mueller-Spitz et al., 2010) and spores would be expected to be more resistant than somatic cells to DNA extraction. Additionally, Cook et al. (2010) reported total cell numbers from qPCR using Clostridia-Eubacteria group primers

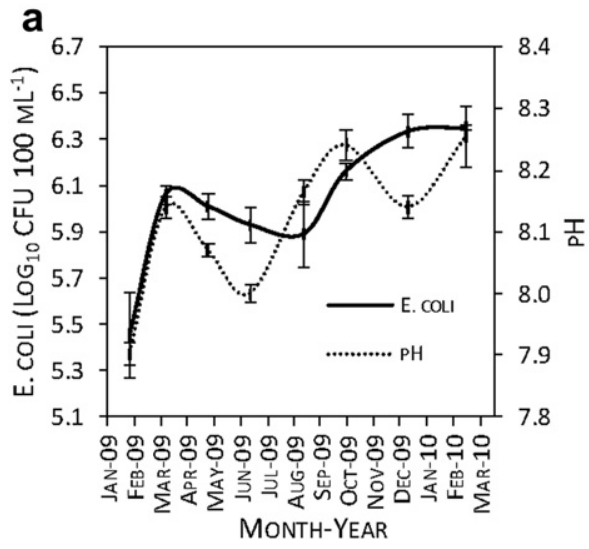

b

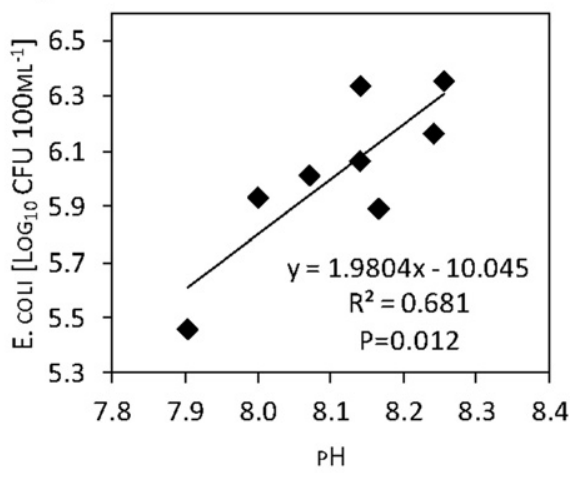

Fig. 6 - Correlation between E. coli and pH in lagoon water. (a) Combined means (4-cm and 1-m samples, $n=12$ ) and standard error bars for collection dates, and (b) linear model of the means. 
that detected multiple genera and species, while cultural methods in the present study detected only C. perfringens.

\section{Conclusions}

This study characterized the water quality of an anaerobic swine manure lagoon over a 14-month period. Temporal and spatial differences in levels of nutrients and bacteria, including zoonotic species, were described and analyzed. These results and the conclusions noted below will enable better informed, safer, and more efficient management and use of anaerobic manure lagoons and other impounded water resources.

- Stratification (higher levels in deeper samples) of most nutrients and C. perfringens, suggested that water samples should be collected at multiple depths to accurately characterize these components of lagoon water quality; however, lack of stratification of most bacterial groups, including E. coli, enterrococci, Campylobacter spp., Listeria spp., Salmonella spp., and staphylococci confirmed that relatively shallow surface samples are adequate for their respective characterizations.

- Temporal changes observed in nutrient and bacterial levels suggests that water samples should be collected at least seasonally for accurate characterization of lagoon water quality.

- An empirical formula (Eq. (2)) developed to estimate annual flux of total $\mathrm{N}$ in anaerobic lagoon water may be a useful and practical tool for managing $\mathrm{N}$ levels in other lagoons.

- Levels of total $\mathrm{N}$ and inorganic $\mathrm{C}$ were highly correlated with water temperature; both accumulated below $19{ }^{\circ} \mathrm{C}$ and declined above $19{ }^{\circ} \mathrm{C}$ with direct implications for increased summertime emissions of ammonia and greenhouse gasses.

- Temporal changes in levels of heavy metals and some bacteria were correlated with other parameters, including: increasing $E$. coli levels with increasing $\mathrm{pH}$; decreasing populations of Campylobacter spp., enterococci, Listeria spp., and Salmonella spp. with increasing temperature; and higher levels of the water-soluble heavy metals $\mathrm{Cu}$, Fe, and $\mathrm{Zn}$, with increasing temperature.

- Levels of the respective bacteria in lagoon water varied significantly during the year, but all species, including zoonotics, were consistently present year-round; thus, the zoonotic species pose ever present, but seasonally changing risks that make risk assessments more complex.

A declining ratio of $\mathrm{N}: \mathrm{P}$ in lagoon water observed during the summer crop irrigation season, suggests the need for testing of nutrient levels during the season, coincident adjustment of irrigation rates, and periodic review and adjustment of nutrient management plans to prevent excess $\mathrm{P}$ accumulations in soils fertilized to meet crop $\mathrm{N}$ demand.

\section{Acknowledgments}

The authors are grateful for the technical assistance of: Cindy Smith and Renotta K. Smith in microbiological laboratory work; Tim Fairbrother, Mary Hardy and Walter Woolfolk in chemical analyses of lagoon water nutrients; and Debbie Boykin in statistical consultation.

\section{R E F E R E N C E S}

Adeli, A., Varco, J.J., 2001. Swine effluent as a source of nitrogen and phosphorus for summer forage grasses. Agronomy Journal 93 (5), 1174-1181.

Aneja, V.P., Chauhan, J.P., Walker, J.T., 2000. Characterization of atmospheric ammonia emissions from swine waste storage and treatment lagoons. Journal of Geophysical Research 105 (D9), 11535-11545.

Aneja, V.P., Arya, S.P., Kim, D.-S., Rumsey, I.C., Arkinson, H.L., Semunegus, H., Bajwa, K.S., Dickey, D.A., Stefanski, L.A., Todd, L., Mottus, K., Robarge, W.P., Williams, C.M., 2008. Characterizing ammonia emissions from swine farms in eastern North Carolina: Part 1-conventional lagoon and spray technology for waste treatment. Journal of the Air and Waste Management Association 58 (9), 1130-1144.

Arrus, K.M., Holley, R.A., Ominski, K.H., Tenuta, M., Blank, G., 2006. Influence of temperature on Salmonella survival in hog manure slurry and seasonal temperature profiles in farm manure storage reservoirs. Livestock Science 102 (3), 226-236.

Blanes-Vidal, V., Nadimi, E.S., Sommer, S.G., 2010. A comprehensive model to estimate the simultaneous release of acidic and basic gaseous pollutants from swine slurry under different scenarios. Chemistry and Ecology 26 (6), 425-444.

Blumenthal, U.J., Mara, D.D., Peasey, A., Ruiz-Palacios, G., Stott, R., 2000. Guidelines for the microbiological quality of treated wastewater used in agriculture: recommendations for revising WHO guidelines. Bulletin of the World Health Organization 78 (9), 1104-1116.

Blunden, J., Aneja, V.P., 2008. Characterizing ammonia and hydrogen sulfide emissions from a swine waste treatment lagoon in North Carolina. Atmospheric Environment 42 (14), 3277-3290.

Bradford, S.A., Segal, E., Zheng, W., Wang, Q., Hutchins, S.R., 2008. Reuse of concentrated animal feeding operation wastewater on agricultural lands. Journal of Environmental Quality 37 (5S), S-97-S-115S.

Bui, X.T., Wolff, A., Madsen, M., Bang, D.D., December 2011. Fate and survival of Campylobacter coli in swine manure at various temperatures. Frontiers in Food Microbiology 2. http:// dx.doi.org/10.3389/fmicb.2011.00262. Available at: http://www. frontiersin.org/food_microbiology/10.3389/fmicb.2011.00262/ abstract (verified 28 Feb. 2012) Article 262.

Burgin, A.J., Yang, W.H., Hamilton, S.K., Silver, W.L., 2011. Beyond carbon and nitrogen: how the microbial energy economy couples elemental cycles in diverse ecosystems. Frontiers in Ecology and the Environment 9 (1), 44-52. http://dx.doi.org/ 10.1890/090227. Available at: http://www.esajournals.org/doi/ abs/10.1890/090227 (verified 28 Feb 2012).

Callaway, T.R., Edrington, T.S., Brabban, A., Kutter, E., Karriker, L., Stahl, C., Wagstrom, E., Anderson, R., Poole, T.L., Genovese, K., Krueger, N., Harvey, R., Nisbet, D.J., 2011. Evaluation of phage treatment as a strategy to reduce Salmonella populations in growing swine. Foodborne Pathogens and Disease 8 (2), 261-266.

Chen, T., Schulte, D.D., Koelsch, K.R., Parkhurst, A.M., 2003. Characteristics of phototrophic and non-phototrophic lagoons for swine manure. Transactions of the American Society of Agricultural Engineers 46 (4), 1285-1292.

Cook, K.L., Rothrock Jr., M.J., Lovanh, N., Sorrell, J.K., Loughrin, J.H., 2010. Spatial and temporal changes in the 
microbial community in an anaerobic swine waste treatment lagoon. Anaerobe 16 (2), 74-82.

Davies, P.R., 2011. Intensive swine production and pork safety. Foodborne Pathogens and Disease 8 (2), 189-201.

DeSutter, T.M., Ham, J.M., 2005. Lagoon-biogas emissions and carbon balance estimates of a swine production facility. Journal of Environmental Quality 34 (1), 198-206.

Door, P.M., Tadesse, D.A., Zewde, B.M., Fry, P., Thakur, S., Gebreyes, W.A., 2009. Longitudinal study of Salmonella dispersion and the role of environmental contamination in commercial swine production systems. Applied and Environmental Microbiology 75 (6), 1478-1486.

Gerba, C.P., Smith Jr., J.E., 2005. Sources of pathogenic microorganisms and their fate during land application of wastes. Journal of Environmental Quality 34 (1), 42-48.

Glass, J.B., Orphan, V.J., Feb 2012. Trace metal requirements for microbial enzymes involved in the production and consumption of methane and nitrous oxide. Frontiers in Microbiological Chemistry 3. http://dx.doi.org/10.3389/ fmicb.2012.00061. Available at: http://www.frontiersin.org/ microbiological_chemistry/10.3389/fmicb.2012.00061/abstract (verified 28 Feb 2012) Article 61.

Guan, T.Y., Holley, R.A., 2003. Pathogen survival in swine manure environments and transmission of human enteric illness a review. Journal of Environmental Quality 32 (2), 383-392.

Harper, L.A., Sharpe, R.R., Parkin, T.B., 2000. Gaseous nitrogen emissions from anaerobic swine lagoons: ammonia, nitrous oxide, and dinitrogen gas. Journal of Environmental Quality 29 (4), 1356-1365.

Hill, V.R., Sobsey, M.D., 2003. Performance of swine waste lagoons for removing Salmonella and enteric microbial indicators. Transactions of the American Society of Agricultural Engineers 46 (3), 781-788.

Ibusuki, T., Aneja, V.P., 1984. Mass transfer of $\mathrm{NH}_{3}$ into water at environmental concentrations. Chemical Engineering Science 39 (7/8), 1143-1155.

Kayranli, B., Scholz, M., Mustafa, A., Hedmark, Å., 2010. Carbon storage and fluxes within freshwater wetlands: a critical review. Wetlands 30 (1), 111-124.

Loughrin, J.H., Quintanar, A.I., Lovanh, N.C., Mahmood, R., 2011. Heat flux measurements and modeling of malodorous compounds above an anaerobic swine lagoon. Water, Air, and Soil Pollution 217 (1-4), 463-471.

Lovanh, N., Loughrin, J.H., Cook, K., Rothrock, M., Sistani, K., 2009. The effect of stratification and seasonal variability on the profile of an anaerobic swine waste treatment lagoon. Bioresource Technology 100 (15), 3706-3712.

McLaughlin, M.R., Brooks, J.P., 2009. Recovery of Salmonella from bermudagrass exposed to simulated wastewater. Journal of Environmental Quality 38 (1), 337-342.

McLaughlin, M.R., Balaa, M.F., Sims, J., King, R., 2006. Isolation of Salmonella bacteriophages from swine effluent lagoons. Journal of Environmental Quality 35 (2), 522-528.

McLaughlin, M.R., Brooks, J.P., Adeli, A., 2009. Characterization of selected nutrients and bacteria from anaerobic swine manure lagoons on sow, nursery, and finisher farms in the Mid-South USA. Journal of Environmental Quality 38 (6), 2422-2430.
McLaughlin, M.R., Brooks, J.P., Adeli, A., Read, J.J., 2010. Comparison of selected nutrients and bacteria from common contiguous soils inside and outside swine lagoon effluent spray fields after long-term use. Journal of Environmental Quality 39 (5), 1829-1840.

Merrill, L., Halverson, L.J., 2002. Seasonal variation in microbial communities and organic malodor indicator compound concentrations in various types of swine manure storage systems. Journal of Environmental Quality 31 (6), 2074-2085.

Mueller-Spitz, S.R., Stewart, L.B., Klump, J.V., McLellan, S.L., 2010. Freshwater suspended sediments and sewage are reservoirs for enterotoxin-positive Clostridium perfringens. Applied and Environmental Microbiology 76 (16), 5556-5562.

Oenema, O., Oudendag, D., Velthof, G.L., 2007. Nutrient losses from manure management in the European Union. Livestock Science 112 (3), 261-272.

Özbelge, T.A., Özbelge, H.O., Tursun, M., 2005. Effects of hydraulic residence time on metal uptake by activated sludge. Chemical Engineering and Processing 44 (1), 23-32.

Placha, I., Venglovsky, J., Sasakova, N., Svoboda, I.F., 2001. The effect of summer and winter seasons on the survival of Salmonella typhimurium and indicator micro-organisms during the storage of solid fraction of pig slurry. Journal of Applied Microbiology 91 (6), 1036-1043.

Sharpley, A., Beegle, D., Bolster, C., Good, L., Joern, B., Ketterings, Q., Lory, J., Mikkelsen, R., Osmond, D., Vadas, P., 2011. Revision of the 590 nutrient management standard: SERA-17 recommendations. Southern Cooperative Series Bulletin 412. Available at: http://www.sera17.ext.vt.edu/ Documents/590Recommends2011.pdf (verified 24 May 2012).

Sistani, K.R., McLaughlin, M.R., Brink, G.E., 2008. Soil nutrient evaluation from swine effluent application to five foragesystem practices. Nutrient Cycling in Agroecosystems 82 (3), 265-271.

USEPA and USAID, 2004. Guidelines for Water Reuse. EPA/625/R04/108.. U.S. Environmental Protection Agency and U.S. Agency for International Development, Washington, DC.

Vanotti, M.B., Szogi, A.A., 2008. Water quality improvements of wastewater from confined animal feeding operations after advanced treatment. Journal of Environmental Quality 37 (5), S-86-S-96.

Webb, J., Menzi, H., Pain, B.F., Misselbrook, T.H., Dämmgen, U., Hendriks, H., Döhler, H., 2005. Managing ammonia emissions from livestock production in Europe. Environmental Pollution 135 (3), 399-406.

Wells, J.E., Oliver, W.T., Yen, J.T., 2010. The effects of dietary additives on faecal levels of Lactobacillus spp., coliforms, and Escherichia coli, and faecal prevalence of Salmonella spp. and Campylobacter spp. in US production nursery swine. Journal of Applied Microbiology 108 (1), 306-314.

Westerman, P.W., Ogejo, J.O., Grabow, G.L., 2010. Swine anaerobic lagoon nutrient concentration variation with season, lagoon level, and rainfall. Applied Engineering in Agriculture 26 (1), 147-152.

WHO, 2006. WHO guidelines for the safe use of wastewater, excreta and greywater. In: Wastewater Use in Agriculture, vol. 2. World Health Organization, Geneva, Switzerland. 